\title{
W SPOMNIENIA
}

\author{
D.to \\ JANUSZ JACEK OdROWĄż-PieniążEK
}

(2 LIPCA 1931 - 8 GRUDNIA 2015)

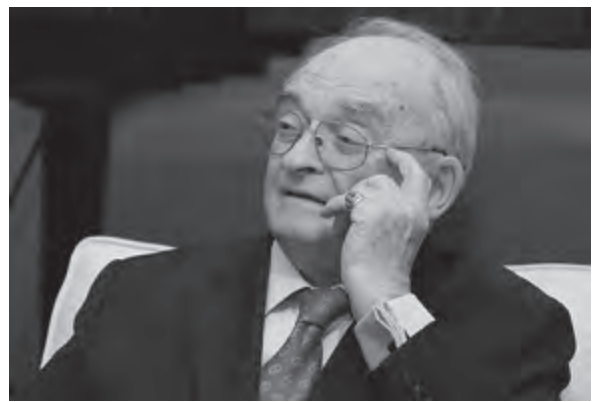

fot. A. Kowalska

ZASŁUŻONY MICKIEWICZOLOG i wieloletni dyrektor Muzeum Literatury im. Adama Mickiewicza urodził się w Opatowicach - w ziemi kujawskiej. O miejscu swego pochodzenia przypominał wielokrotnie, w swych opowiadaniach literackich, a także książką Rodem z Kujaw, opracowaną przez Krystynę Sarnowską. Gdy niemiecki okupant zmusił rodzinę do opuszczenia rodowej siedziby, czas wojny wraz z matką spędził w Warszawie i jej okolicach (ojciec zginął w 1941 roku w niemieckim obozie Mauthausen-Gusen). Po wojnie ukończył Gimnazjum im. ks. Jana Długosza we Włocławku - należał do ostatniego rocznika maturalnego szkoły zlikwidowanej za zbyt opieszałe realizowanie zaleceń komunistycznej władzy. Jako piętnastolatek debiutował w miejscowym dzienniku „Wiadomości Włocławskie”. Szkolnemu poloniście zawdzięczał swe literackie zainteresowania i wybór studiów: w 1949 roku rozpoczął studiowanie polonistyki na Uniwersytecie Warszawskim (dodatkowo przez rok był studentem rusycystyki). Gdy po uzyskaniu dyplomu zawodowego ze specjalizacją bibliotekarską nie został przyjęty na studia magisterskie (z powodu nieprawomyślnych felietonów i wynikłego w następstwie skandalu redakcyjnego), poznawanie literatury kontynuował na Katolickim Uniwersytecie Lubelskim. Już wtedy zaczął publikować swe prace literackie: debiutancki wiersz, potem opowiadania, które cieszyły się dużą poczytnością. Był też publicystą kilku czasopism, pisał felietony, reportaże i korespondencje dla „Słowa 
Powszechnego”, „Przeglądu Powszechnego”, „Dziś i Jutro”, „Kuriera Polskiego”, „Stolicy”, „Poznaj Świat”. Przez krótki czas uprawiał krytykę literacką.

Przygotowanie do późniejszej wielostronnej działalności zawodowej Janusza Odrowąż-Pieniążka stanowiła praca w Instytucie Badań Literackich PAN (w Pracowni Edytorstwa i Dokumentacji Naukowej Literatury XIX wieku) w latach 19561972. Podczas wielokrotnych wyjazdów zagranicznych (głównie do Paryża) zaznajamiał się z archiwami romantyków, a przede wszystkim Adama Mickiewicza. Efektem biblioteczno-archiwalnych rozpoznań stała się opublikowana w 1968 roku książka Listy do Adama Mickiewicza w Muzeum Adama Mickiewicza w Paryżu. Autor Pana Tadeusza pozostał obiektem zainteresowań i działalności zawodowych do końca życia Janusza Odrowąż-Pieniążka. Ale pojawili się też inni „bohaterowie”; krajan Gustaw Zieliński, „piewca wolności i syberyjskich stepów”, którego wybór twórczości opublikował w tomie Kirgiz i inne poezje już w 1956; sylwetka pisarza zesłańca intrygowała go jeszcze dwadzieścia lat później. Przez długie lata zajmował się też przyjacielem i korespondentem Zielińskiego, Ignacym Orpiszewskim, także zadomowionym w stronach rodzinnych Odrowąż-Pieniążków. Trzecim z grupy zesłańców był Adolf Januszkiewicz - Dzieje mickiewiczowskiego Adolfa ogłosił także w 1956 roku.

Przygody z Mickiewiczem przyszły dyrektor muzeum jego imienia rozpoczął wcześnie, bo już w czasie studiów, jako sekretarz (w latach 1954-1956) Komitetu Redakcyjnego Wydania Jubileuszowego Dzieł pisarza. Prace edytorskie nad tą spuścizną kontynuował następnie (od 1967 roku) jako sekretarz Komitetu Redakcyjnego Dzieł wszystkich pod redakcją Konrada Górskiego. Choć edycja zakończyła się niepowodzeniem po wydaniu dwóch tomów, publikacje Odrowąż-Pieniążka, dotyczące Mickiewicza, ukazywały się systematycznie przez następne dziesięciolecia. Do najważniejszych należy książka Mickiewicziana zbierane po świecie (1998), ale zainteresowanie czytelników i badaczy budziły także pojedyncze artykuły o charakterystycznych tytułach: Nieznany list Adama Mickiewicza (1972); Trzy listy Adama Mickiewicza (1975); Cztery nieznane listy Adama Mickiewicza 1830-1852 (1987); "Żadne żaby tak pięknie nie graja jak polskie”. Nieznany autograf karty „Pana Tadeusza" (1987); Montresorskie zagadki Mickiewiczowskie (1997). Własne rozpoznania uzupełniały wstępy i posłowia do cudzych publikacji, między innymi: Mickiewiczianów w zbiorach Tomasza Niewodniczańskiego w Bitburgu (1989), Listów z Syberii Adolfa Januszkiewicza, Moich wędrówek po obczyźnie Karola Frankowskiego oraz reprintu pierwodruku Pana Tadeusza. Prace edytorskie autora Muzeów Adama Mickiewicza na świecie zostały uhonorowane nagrodą Polskiego PEN Clubu w 1998 roku.

W 1972 roku Janusz Odrowąż-Pieniążek został dyrektorem Muzeum Literatury im. Adama Mickiewicza (tuż po tym, jak Rada Warszawy zmieniła formułę wcześniejszego Muzeum Adama Mickiewicza) i redaktorem naczelnym wydawnictwa ciągłego: „Blok-Notes Muzeum Literatury”. Zarządzał tą instytucją przez trzydzieści siedem lat, a praktycznie trwał w niej do śmierci. Kontynuował wspaniałe tra- 
dycje dyrektorów mickiewiczologów: Aleksandra Semkowicza i Leonarda Podhorskiego-Okołowa. Dzięki jego przedsiębiorczości do muzeum trafiły ważne nabytki związane z autorem Pana Tadeusza, ale też z innymi pisarzami. W 1998 roku tak podsumował swe działania dyrektorskie: „Nasze wystawy są zapewne najbardziej spektakularnym fragmentem pracy muzeum, i oczywiście przywiązujemy do nich wielką wagę, ale w moim odczuciu najważniejsze jest gromadzenie zbiorów, chronienie dokumentów polskiej kultury. Bardzo boleję, kiedy coś ważnego przepada, dlatego wszelkimi sposobami zbieram wszystko, co się da” („Nowe Książki” 1998, $\mathrm{nr}$ 12); istotnie, zgromadził setki kilogramów dokumentów papierowych i innych świadectw życia literackiego. Ponadto pisał przedmowy i posłowia do katalogów licznych wystaw organizowanych w niezwykłej atmosferze kamieniczek przy Rynku Starego Miasta (m.in. o wileńskiej Celi Konrada) oraz publikacji poświęconych tej instytucji (Muzeum Literatury im. Adama Mickiewicza; Haliny Natuniewicz Zbiory i prace polonijne Muzeum Literatury im. Adama Mickiewicza w Warszawie; Polskie muzea literackie Małgorzaty Kucza-Kuczyńskiej). Jest autorem ważnych opracowań poświęconych polskiemu muzealnictwu: Problematyka muzeów literatury w Polsce (1980); Muzeum Literatury im. Adama Mickiewicza w Warszawie (1992). Zakres jego dyrektorskich działań dobrze oddają książki: Mickiewicziana zbierane po świecie (1998) oraz Polonika zbierane po świecie (1992; jej recenzja Jacka Wierzbińskiego w „Nowych Książkach” ma tytuł Polska w świecie). To wyjątkowe, nie mające odpowiedników szkice o przygodach badacza „spraw polskich” - dokumentalisty, bibliotekarza, muzealnika, ale też biografa i historyka literatury. Uzupełniają dzieje polskiego piśmiennictwa pięknego świadectwami z życia pisarzy, ujawniają mistyfikacje, wskazują tropy naukowe. Między wierszami możemy odnaleźć wzmianki o pasjach zawodowych i literackich, ale też o sprawach „zwyczajnie ludzkich" ich autora. W tych sprawozdaniach kryją się opowieści o wysiłku zdobywania poloników - bez chełpliwości, choć powodów do dumy było sporo. Żywej obecności Janusza Odrowąż-Pieniążka w życiu polonistycznym w Polsce i na świecie towarzyszyło bowiem jakże skromne, a przecież nie zawsze cenione przeświadczenie: „odwołuję się tylko i wyłącznie do faktów”; czyniło go ono niejednokrotnie zażartym polemistą $\mathrm{w}$ dyskusjach $\mathrm{z}$ zagubionymi w sobie konstruktorami polskiego życia.

Praktyka muzealna owocowała stanowiskami w stowarzyszeniach muzealnych, także o zasięgu światowym (m.in. w Międzynarodowym Komitecie Muzeów Literackich) oraz stanowiskiem redaktora naczelnego czasopisma „Muzealnictwo”.

Najważniejszym periodykiem był dla Janusza Odrowąż-Pieniążka jednak „Blok-Notes Muzeum Literatury”; redaktor naczelny publikował niemal w każdym tomie (przywołane wcześniej artykuły o odkrywanych listach oraz innych autografach Mickiewicza, a także pomniejszych postaci romantyzmu), ale też wstępy do poszczególnych roczników, prace o historii i działalności staromiejskiej placówki (Geneza i historia Muzeum Literatury), redagował dział „Miscellanea Mickiewiczowskie”; zachęcał badaczy do opracowywania archiwalnych i historycznoliterackich 
nabytków muzeum, a także do dyskusji o formach pracy muzeum literatury i muzeum literackiego. Dzięki jego aktywności mickiewiczowskie muzeum miało swój niepodważalny udział w bieżącym życiu literackim, było chyba najważniejszym salonem Warszawy (dokumentowały to kolejne „odcinki” kroniki Muzeum Literatury). Upamiętniał zasłużonych muzealników literackich w Polsce i na świecie, publikując ich sylwetki w „Blok-Notesie” (sam pisał np. o Teodorze F. Domaradzkim z uniwersytetu w Kanadzie i swym poprzedniku Adamie Mauersbergerze).

Działalności zawodowej dyrektora Muzeum Literatury sprzyjała pasja podróżnicza. Zaczął ją realizować zaraz po studiach. Po 1956 roku objechał niemal cały świat, najczęściej kierował się do Francji (Biblioteka Polska w Paryżu i zamek Branickich w Montresor), Turynu (archiwum Towiańskiego gromadzone przez rodzinę Begeyów), ale też do Anglii, Skandynawii, Kanady, USA, Meksyku. Najbardziej nieprawdopodobna była wyprawa na Syberię i do Kazachstanu w 1965 roku, szlakiem swych literackich bohaterów: Gustawa Zielińskiego, Adolfa Januszkiewicza, Ignacego Orpiszewskiego. Plonem każdej wyprawy były znaleziska, inicjujące w przyszłości kontakty z ludźmi, cenne inicjatywy. A także publikacje - prace naukowe, ale też korespondencje prasowe i drobne utwory prozą. Wydane w 1963 roku Opowiadania paryskie miały cztery następne wydania (pt. Cocktail u księżny Georgijew), co bezspornie było ewenementem; nie mniejszym zainteresowaniem cieszyło się Małżeństwo z Lynda Winters albo Pamiątka po Glorii Swanson (1971, także pięć wydań), Teoria fal (1964), Ucieczka z cieplych krajów (1966), Party na calle Guatemala (1974), Mit Marii Chapdelaine (1985); Bulwar Wilshire albo Lądowanie w Kyzyt Kija (2004), a ponadto wybór z wcześniejszej twórczości Wielki romans w Bucharze (1984) i zawierający juwenilia Głos z szuflady (2002). Czytelników fascynował podtekst autobiograficzny opowiadań, niecodzienne realia wynikające ze szczególnych wojaży autora, ale też spajające je elementy fikcji literackiej; powszedniość i osobliwości, dystans wobec „władców dziejów” i niezaprzeczalny humor - wobec siebie i prób narzucanych przez „los”.

Janusz Odrowąż-Pieniążek był członkiem licznych towarzystw społecznych i naukowych (najczęściej pełnił w nich ważne funkcje członka zarządu, wiceprezesa, prezesa, prezydenta): Towarzystwa Przyjaciół Książki, ZAiKS-u, Związku Literatów Polskich, Stowarzyszenia Pisarzy Polskich, Narodowej Rady Kultury, Stowarzyszenia Autorów Dzieł Literackich, Stowarzyszenia Kultury Europejskiej; Międzynarodowego Komitetu Muzeów Literackich; współzakładał Fundację Kultury Polskiej. Pod koniec życia zgłosił swój akces do Polskiego Towarzystwa Ziemiańskiego i Polskiego Towarzystwa Heraldycznego.

Ważnym miejscem realizowania pasji mickiewiczologicznych oraz popularyzowania życia naukowego stało się dla Janusza Odrowąż-Pieniążka Towarzystwo Literackie im. Adama Mickiewicza, którego członkiem został w 1952 roku. Od 1982 roku uczestniczył w jego pracach jako członek Zarządu Głównego; między innymi w marcu 2006 roku przewodniczył uroczystemu zebraniu z okazji sto dwudziestej rocznicy założenia Towarzystwa. Podczas Zjazdu Delegatów Towarzystwa 
Literackiego we wrześniu 1995 roku został wybrany na Przewodniczącego Polskiego Komitetu Obchodów Dwusetnej Rocznicy Urodzin Adama Mickiewicza. Przez cztery lata animował liczne przedsięwzięcia, zarówno popularyzujące osobę i dzieło poety, jak też inicjujące prace badawcze nad spuścizną autora Pana Tadeusza (był m.in. współorganizatorem międzynarodowej konferencji naukowej Adam Mickiewicz. Tradycja i nowatorstwo, która odbywała się w Warszawie i Poznaniu w październiku 1998 roku). Żadne wydarzenie rocznicowego roku nie dokonało się bez wiedzy, a zazwyczaj i obecności, dyrektora Muzeum Literatury (był m.in. w Damaszku, gdzie wygłosił kilka odczytów dla zróżnicowanej publiczności). Sprawozdanie opublikowane przez Przewodniczącego Komitetu zajmuje w „Blok-Notesie" kilkanaście stron, a ma charakter naprawdę rejestracyjny. Warto przypomnieć, że dzięki rozlicznym inicjatywom pod patronatem dyrektora warszawskiego Muzeum Literatury w jubileuszowym roku odnaleziono cztery nieznane listy Mickiewicza oraz uważany za zaginiony autograf autorskiego przekładu Farysa na język francuski. Dopiero pod koniec życia dyrektor mickiewiczolog stwierdził niejako z żalem, że Mickiewicz „ «pisze» już dziś rzadziej”.

Janusz Odrowąż-Pieniążek kilkakrotnie publikował w „Roczniku Towarzystwa Literackiego im. Adama Mickiewicza" (m.in. nekrologi i wspomnienia o Samuelu Fiszmanie oraz Marii Danilewicz Zielińskiej). Za swe liczne działania na rzecz Towarzystwa podczas Zjazdu Delegatów w Białymstoku w 2001 roku otrzymał zasłużony ty tuł Członka Honorowego Towarzystwa Literackiego im. Adama Mickiewicza.

Teresa Winek

\section{菖 \\ JANUSZ ODROWĄŻ-PIENIĄŻEK - NASZ DYREKTOR}

Janusz Odrowąż-Pieniążek był dyrektorem Muzeum Literatury im. Adama Mickiewicza w Warszawie w latach 1972-2009. Po przejściu na emeryturę pracował nadal, aż do śmierci. Poświęcił Muzeum czterdzieści trzy lata swego życia i 8 grudnia 2015 roku dołączył do grona swych znakomitych poprzedników, Aleksandra Semkowicza, Leonarda Podhorskiego-Okołowa i Adama Mauersbergera, których prace kontynuował. W Muzeum na drzwiach pokoju, w którym pracował przez sześć ostatnich lat, nadal wisi tabliczka Gabinet dyrektora Janusza Odrową̇-Pieniążka. A jego fotograficzny portret został dołączony do galerii wielkich dyrektorów w czytelni Muzeum.

Za jego dyrekcji Muzeum znacznie powiększyło swoje zbiory, przede wszystkim rękopiśmienne i biblioteczne. Pozyskało, często dzięki osobistym kontaktom i staraniom Dyrektora, duże kolekcje mickiewiczowskie oraz archiwa znakomitych twórców dwudziestowiecznych. Rozwinęło własny styl wystawienniczy, w którym o dziele literackim mówi się językiem artystycznym. Było salonem stolicy.

Zespół muzealny był zintegrowany. Wspólnie pracowaliśmy, wspólnie też nieraz świętowaliśmy. W 1992 roku, w dwudziestolecie pracy Dyrektora, przygotowa- 
liśmy - szumnie mówiąc - program artystyczny. Kustosz Łukasz Kossowski odczytał satyryczny tekst (swego autorstwa) tyczący analizy nazwiska Dyrektora, po czym nastąpiła parodystyczna inscenizacja (w wykonaniu pracowników) Opowiadań paryskich i Cocktailu u księżny Georgijew. Na zachowanych fotografiach widać rozbawionego Dyrektora i jego roześmianą Małżonkę. Z kolei w roku 2002, kiedy to obchodziliśmy pięćdziesięciolecie działalności Muzeum, po oficjalnych przemówieniach i pięknej laudacji profesora Stanisława Makowskiego, zaprezentowano nieznany list Adama Mickiewicza, adresowany do rodaka z Wielkopolski imieniem Janusz. Dyrektor przyjął to $\mathrm{z}$ humorem i gratulował autorom tego falsyfikatu.

Jako redaktor naczelny Blok-Notesu Muzeum Literatury im. Adama Mickiewicza preferował wprawdzie mickiewicziana i wiek XIX, ale dużo uwagi poświęcał też literaturze współczesnej.

Janusz Odrowąż-Pieniążek był prawym, mądrym i dobrym człowiekiem. Miał ogromną wiedzę, ale zawsze z radością witał nasze ustalenia czy uściślenia tyczące biografii twórców oraz tekstów literackich. Równocześnie dzielił się z nami własnymi odkryciami. Nie stwarzał dystansu. Bardzo to ceniliśmy i darzyliśmy go szacunkiem i sympatią. Interesował się naszymi pracami. Pamiętam wzruszenie, jakie mnie ogarnęło, gdy przed laty, po powrocie z urlopu, ujrzałam na biurku list: „Znalazłem w moich notatkach spisane kiedyś z egzemplarza Memorandum Attilia Begeya uzupełnienia dotyczące towiańczyków, przekazuję kserokopie tychże do Pani teczki. - J. O. Pieniążek". Katalogowałam wtedy papiery rodziny Towiańskich. Szczególnie wdzięczna jestem Dyrektorowi za wsparcie, jakiego mi udzielał, kiedy przygotowywałam do publikacji część listów do Adama Mickiewicza. Cieszę się, że dane mi było pracować pod kierunkiem Janusza Odrowąż-Pieniążka. 